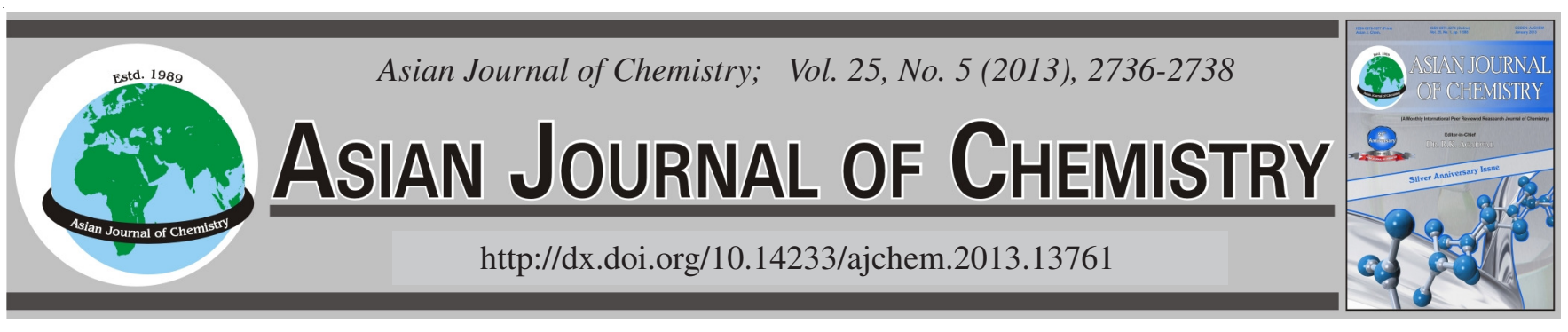

\title{
Spectrophotometric Determination of Cationic Surfactant with Titan Yellow
}

\author{
Ying-Hong Liu ${ }^{1, *}$, Hong-Wei Zhan ${ }^{2}$ and Wei-Xing MA ${ }^{1}$
}

${ }^{1}$ College of Chemical Engineering, Huaihai Institute of Technology, Lianyungang 222005, Jiangsu Province, P.R. China

${ }^{2}$ Jiangsu Lvyuan Engineering Design Research Co. Ltd., Lianyungang 222000, Jiangsu Province, P.R. China

*Corresponding author: Tel: +86 518 85857922; E-mail: liuyh9506@163.com; yinghong1978@yahoo.com.cn

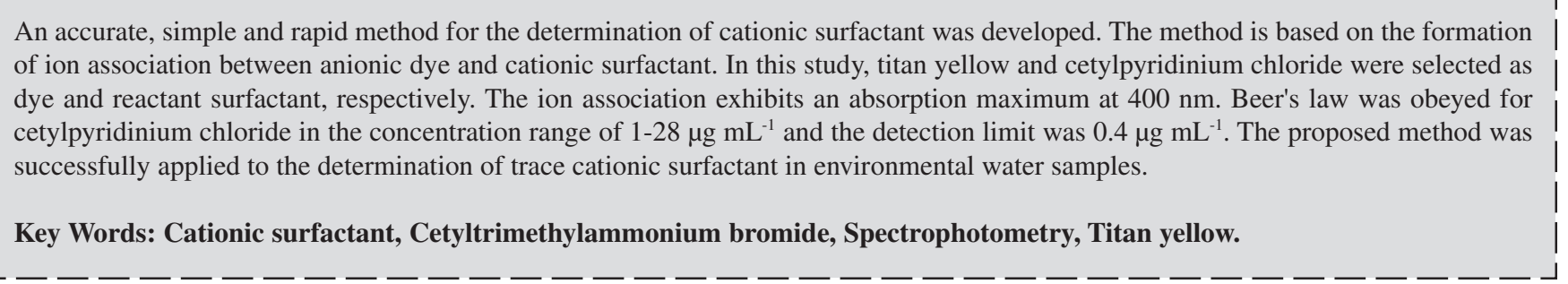

\section{INTRODUCTION}

Cationic surfactants (CS) are widely used as fabric softener, frother, hair conditioner, fermicide and emulsifier in many industrial fields. In recent years, more and more waste water containing mass cationic surfactants was flowed into river and sea, which leaded to the eutrophication of water. It was very harmful to the health of human body and aquatic organisms. So it is significant to study on the determination method of cationic surfactants. Several techniques, such as spectrophotometry ${ }^{1-5}$, fluorometry ${ }^{6}$, liquid chromatography ${ }^{7}$ and photometric titration $^{8}$ etc., have been reported for the determination of cationic surfactants. The reagents, e.g., orange II, disulfine blue, ethyl orange, patent blue $\mathrm{V}$, tetrabromophenolphthalein ethyl ester have been reported for determination of cationic surfactants based on extraction of the ion associates between cationic surfactant and anionic dyes. These spectrophotometric methods have the disadvantages of tedious procedures and the use of toxic solvents.

In this work, a new spectrophotometric method for the determination of cationic surfactant without extraction was proposed. The method was based on the colour reaction of cationic surfactant with titan yellow (TY). The determination was carried out directly in aqueous solution and was successfully applied to the determination of cationic surfactant in environmental water samples.

\section{EXPERIMENTAL}

A 722-N spectrophotometer (Shanghai precision \& Scientific Instrument Co. Ltd., China) with matched $1 \mathrm{~cm}$ glass cells was used for all the spectrophotometric determination.
The standard stock solution $\left(1 \mathrm{~g} \mathrm{~L}^{-1}\right)$ of cetylpyridinium chloride was prepared by dissolving $0.1000 \mathrm{~g}$ of cetylpyridinium chloride in $100 \mathrm{~mL}$ volumetric flask with water. The cetylpyridinium chloride standard working solutions were obtained by diluting the above stock solution. Titan yellow solution $\left(0.5 \mathrm{~g} \mathrm{~L}^{-1}\right)$ was prepared by dissolving $0.5000 \mathrm{~g}$ titan yellow in $1000 \mathrm{~mL}$ water. $0.01 \mathrm{~mol} \mathrm{~L}^{-1} \mathrm{NaOH}$ solution was used. All chemicals used were of analytical grade and double distilled water was used throughout the study.

Procedure: A suitable volume of cetylpyridinium chloride standard working solution or sample solution was transferred into a $10 \mathrm{~mL}$ colorimetric tube. $1.5 \mathrm{~mL}$ of $\mathrm{NaOH}$ solution and $1.5 \mathrm{~mL}$ of titan yellow solution was added. The solution was diluted to the mark with water and kept aside for $5 \mathrm{~min}$. The reagent blank solution which was absence of cetylpyridinium chloride was prepared as above. The absorbance A of the solution was measured at $400 \mathrm{~nm}$ with $1 \mathrm{~cm}$ cells by using reagent blank solution as reference.

\section{RESULTS AND DISCUSSION}

Absorption spectra: The absorption spectra of the titan yellow and cetylpyridinium chloride-titan yellow ion association complex were shown in Fig. 1. It could be found that the maximum absorbance of titan yellow was located at 405 $\mathrm{nm}$. The addition of cetylpyridinium chloride to titan yellow resulted in the absorbance decreasing at 380-450 $\mathrm{nm}$ and increasing at 450-540 nm, which indicated the formation of ion association complex between cetylpyridinium chloride and titan yellow. The maximum absorption wavelength of the 


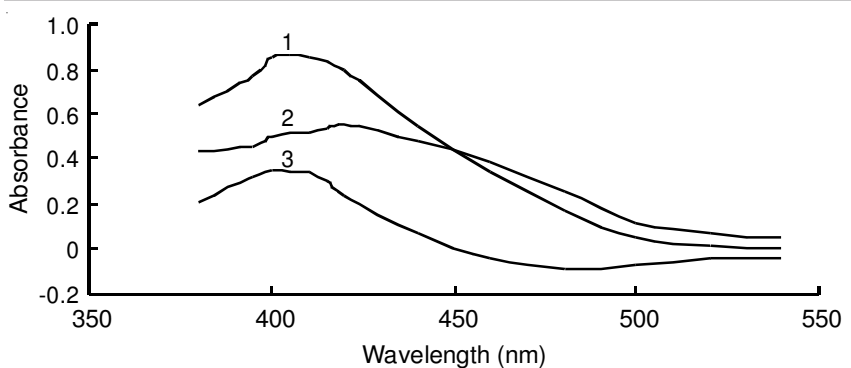

Fig. 1. Absorption spectra: $50 \mathrm{mg} \mathrm{L}^{-1}$ titan yellow, $20 \mathrm{mg} \mathrm{L}^{-1}$ cetylpyridinium chloride, $1.5 \times 10^{-3} \mathrm{~mol} \mathrm{~L}^{-1} \mathrm{NaOH}$

complex was at $400 \mathrm{~nm}$ and the wavelength was selected as the measurement wavelength.

Effect of pH: The dependence of absorbance on $\mathrm{pH}$ in phosphoric acid buffer and sodium hydroxide solution in the range of 9.0-14.0 was studied and the results was shown in Fig. 2. It could be found that the maximum absorbance was occurred at $\mathrm{pH} 12.0$ and so $0.01 \mathrm{~mol} \mathrm{~L}^{-1} \mathrm{NaOH}$ solution was selected. The effect of $\mathrm{NaOH}$ solution volume was investigated and the results showed that the absorbance reached maximum and kept constant at the range of 1.0-3.0 mL (Fig. 3). For further work, $1.5 \mathrm{~mL}$ of $0.01 \mathrm{~mol} \mathrm{~L}^{-1} \mathrm{NaOH}$ solution was selected as the optimal.

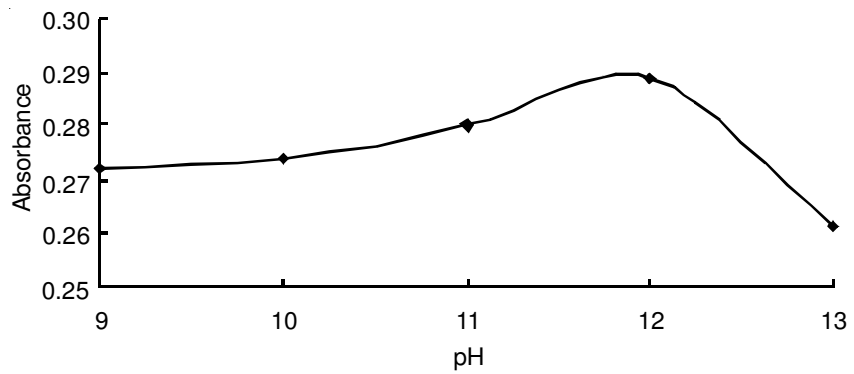

Fig. 2. Effect of $\mathrm{pH}: 50 \mathrm{mg} \mathrm{L}^{-1}$ titan yellow, $20 \mathrm{mg} \mathrm{L}^{-1}$ cetylpyridinium chloride

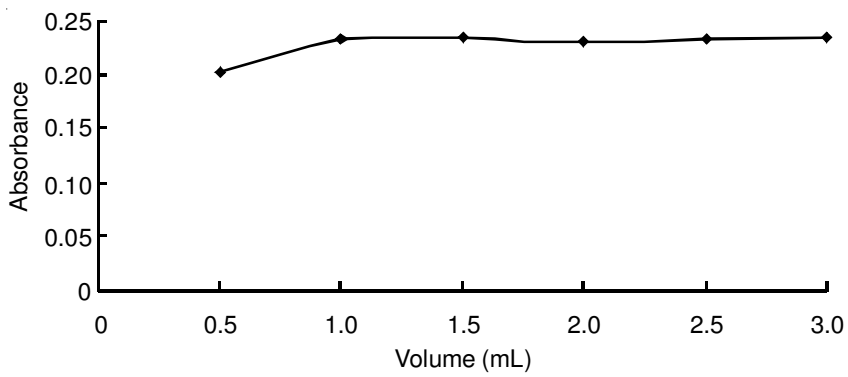

Fig. 3. Effect of $\mathrm{NaOH}$ solution volume: $50 \mathrm{mg} \mathrm{L}^{-1}$ titan yellow, $20 \mathrm{mg} \mathrm{L}^{-1}$ cetylpyridinium chloride

Effect of titan yellow dosage: The effect of titan yellow solution dosage on the absorbance was explored and the results were showed in Fig. 4. It was obviously from the data that the absorbance was maximum and steady in the concentration range of 1-2 mL. Therefore, $1 \mathrm{~mL}$ of titan yellow solution was used in this study.

Effect of reaction time and stabililty: The effect of reaction time was studied. As shown in Fig. 5, cetylpyridinium chloride reacted with titan yellow within at most 1 min at room temperature. The ion association remained steady at least $0.5 \mathrm{~h}$

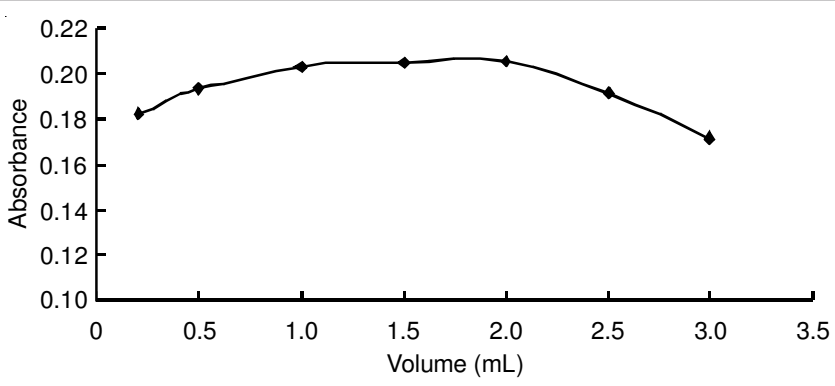

Fig. 4. Effect of titan yellow dosage: $20 \mathrm{mg} \mathrm{L}^{-1}$ cetylpyridinium chloride, $1.5 \times 10^{-3} \mathrm{~mol} \mathrm{~L}^{-1} \mathrm{NaOH}$

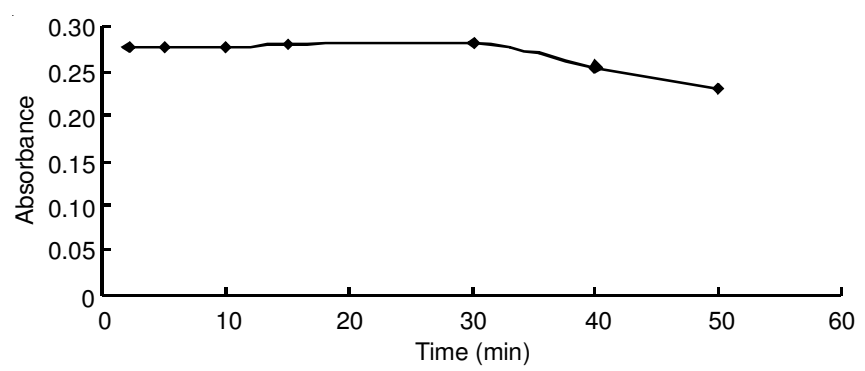

Fig. 5. Effect of time: $50 \mathrm{mg} \mathrm{L}^{-1}$ titan yellow, $20 \mathrm{mg} \mathrm{L}^{-1}$ cetylpyridinium chloride, $1.5 \times 10^{-3} \mathrm{~mol} \mathrm{~L}^{-1} \mathrm{NaOH}$

Effect of interference: To study the selectivity of the proposed method, the effect of foreign species on the determination of $20 \mu \mathrm{g} \mathrm{mL}^{-1}$ cetylpyridinium chloride was tested. When the relative error was within $\pm 5 \%$, the allowable amounts of foreign ions were shown in Table-1. The interference of $\mathrm{Ni}^{2+}, \mathrm{Fe}^{2+}, \mathrm{Cu}^{2+}, \mathrm{Cr}^{3+}$ could be greatly diminished by addition of $2 \mathrm{~mL} 0.02 \mathrm{~mol} \mathrm{~L}^{-1}$ EDTA solution.

\begin{tabular}{lc}
\multicolumn{2}{c}{ TABLE-1 } \\
EFFECT OF FOREIGN IONS \\
\hline \multicolumn{1}{c}{ Foreign ions } & Allowable amount $\left(\omega_{\text {ion }} / \omega_{\mathrm{CPC}}\right)$ \\
\hline $\mathrm{K}^{+}, \mathrm{Na}^{+}, \mathrm{Ca}^{2+}, \mathrm{Mg}^{2+}, \mathrm{Cl}^{-}, \mathrm{NO}_{3}^{-}$ & 500 \\
$\mathrm{Fe}^{3+}, \mathrm{Al}^{3+}, \mathrm{F}^{-}$ & 200 \\
$\mathrm{Hg}^{2+}, \mathrm{Zn}^{2+}, \mathrm{Bi}^{3+}$, & 100 \\
$\mathrm{Ni}^{2+}, \mathrm{Fe}^{2+}, \mathrm{Cu}^{2+}, \mathrm{Cr}^{3+}, \mathrm{IO}_{3}^{-}$ & 10 \\
\hline
\end{tabular}

Working curve and detection limit: A series of standard cetylpyridinium chloride solutions with different concentration were prepared. Under the chosen experimental conditions, the absorbance of these solutions was measured. The working curve was drawn and shown in Fig. 6. The results showed that Beer's law was obeyed in the range of $1-28 \mu \mathrm{g} \mathrm{mL}^{-1}$ for cetylpyridinium chloride. The linear regression equation was $\mathrm{A}=$ $0.0105 c+0.0649$ with the regression coefficient $\gamma=0.9993$. The reagent blank was determined 11 times and the detection limit determined was $0.4 \mu \mathrm{g} \mathrm{mL}^{-1}$ by $3 \mathrm{~S} / \mathrm{K}$ method ( $\mathrm{S}$ is the standard deviation of the reagent blank for 11 times determination, $\mathrm{K}$ is the slope of the working curve).

Application: To investigate the application of the proposed method, it was applied to the determination of cationic surfactant in river and drinking water. River water was filtrated and drinking water was concentrated five times as sample solutions. $1.0 \mathrm{~mL}$ of sample solution was transferred into a colorimetric tube and determined by the proposed method. The standard addition recovery experiments were made also. The analysis results were shown in Table-2. It could be calculated from the 


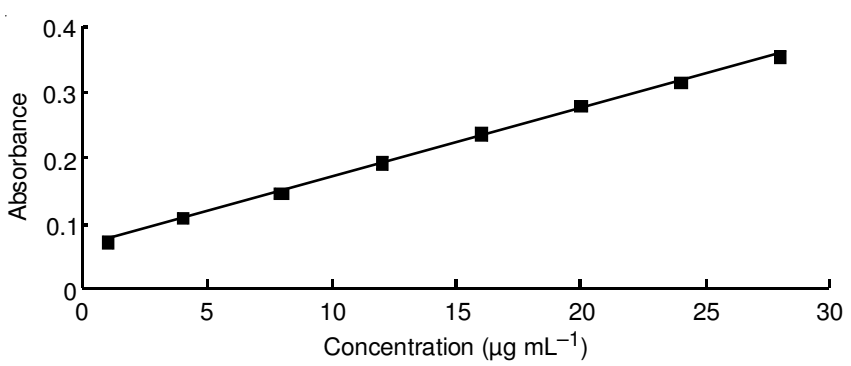

Fig. 6. Working curve: $50 \mathrm{mg} \mathrm{L}^{-1}$ titan yellow, $1.5 \times 10^{-3} \mathrm{~mol} \mathrm{~L}^{-1} \mathrm{NaOH}$

\section{TABLE-2}

ANALYTICAL RESULTS OF SAMPLES

\begin{tabular}{|c|c|c|c|c|c|}
\hline Sample & $\begin{array}{c}\text { Found } \\
(\mu \mathrm{g} \\
\left.\mathrm{mL}^{-1}\right)\end{array}$ & $\begin{array}{l}\text { RSD } \\
(\%)\end{array}$ & $\begin{array}{c}\text { Added } \\
\quad(\mu \mathrm{g} \\
\left.\mathrm{mL}^{-1}\right) \\
\end{array}$ & $\begin{array}{c}\text { Recovered } \\
\left(\mu \mathrm{g} \mathrm{mL} L^{-1}\right)\end{array}$ & $\begin{array}{c}\text { Recovery } \\
(\%)\end{array}$ \\
\hline River 1 & 5.82 & 1.7 & 5.00 & 4.98 & 99.6 \\
\hline River 2 & 4.83 & 1.6 & 5.00 & 4.98 & 99.6 \\
\hline $\begin{array}{l}\text { Drinking } \\
\text { water }\end{array}$ & 4.51 & 1.1 & 5.00 & 5.06 & 101.2 \\
\hline
\end{tabular}

data that the concentration of cetylpyridinium chloride in river 1 , river 2 and drinking water samples before treatment were 58.2, 48.3 and $9.0 \mu \mathrm{g} \mathrm{mL}^{-1}$, respectively.

\section{Conclusion}

An easy, rapid and inexpensive spectrophotometric method for the determination of cetylpyridinium chloride was established. The method was used in the determination of cationic surfactant in environmental water samples and the results obtained were precise and accurate.

\section{REFERENCES}

1. G.V. Scott, Anal. Chem., 40, 768 (1968).

2. H.K. Biswas and B.M. Mandal, Anal. Chem., 44, 1636 (1972).

3. S. Motomizu and Y.H. Gao, Microchem. J., 49, 326 (1994).

4. M. Idouhar and A. Tazerouti, J. Surfactants Deterg., 11, 263 (2008).

5. K. Toei, S. Motomizu and T. Umano, Talanta, 29, 103 (1982).

6. B. Zhang and H.P. Beck, Anal. Lett., 35, 2511 (2002).

7. C.R. Harrison and C.A. Lucy, J. Chromatogr. A, 956, 237 (2002).

8. T. Masadome, Anal. Lett., 37, 499 (2004). 